\title{
The Local Wisdom of Tenggerese People in Karo Ritual
}

\author{
Trisakti \\ Universitas Negeri Surabaya \\ Surabaya, Indonesia \\ trisakti@unesa.ac.id
}

\author{
Anik Juwariyah \\ Universitas Negeri Surabaya \\ Surabaya, Indonesia \\ anikjuwariyah@unesa.ac.id
}

\begin{abstract}
Karo is a big day celebrated annually by Tenggerese people as a worship towards the God and a homage to the ancestors' spirit. During Karo, the Tenggerese people perform a set of ritual activities. The ritual starts from signing the existence of the ancestors' spirit until signing the return of it. Furthermore, this study used qualitative descriptive method for investigating and explaining deeply the local wisdom in Karo ritual. The data were collected by observing the ritual activities starting from its implementation until the ceremony of Karo. In this study, the data collection technique used documentation and in-depth interview with the elders and the people. The results found that Karo ritual which becomes the local wisdom of Tenggerese's tradition is the obedience tradition and it is believed by the people as a ritual for obtaining people welfare, tranquility, and peace.
\end{abstract}

\section{Keywords—local wisdom; Tenggerese people; Karo ritual}

\section{INTRODUCTION}

Karo ritual is a religious big day that is still currently carried out by Tenggerese people as a worship towards the ancestors and a gratitude of the blessings they got for the past year. It is done by Tenggerese on the second month in heritage calendar, that is the seventh day of 22 of Karo month and it performs for 15 days. Several rituals are done by the Tenggerese people, both in family and in community scope. The ritual done in family scope orients to the elements of worship towards the ancestors and gratitude dealing with the blessings that they gave to the family. Meanwhile, the Karo ritual activities in community scope done by all the villagers together is a worship towards the ancestors who have kept the village as well as it is a gratitude due to the blessings and protection that the ancestors give to the villagers. The Tenggerese' solidarity is very strong. Appreciation, cooperation, and respect are the local wisdoms that are interesting to investigate. The togetherness that old people and young people deal with, shapes intimacy towards the people [1]. That thing makes Tenggerese people strong in terms of their culture and they keep the adiluhung cultural values bequeathed by Tenggerese's ancestors.

Tenggerese people have a belief on the big role of nature in people's lives. The world takes place by uniting pusura and prakerti which are important to celebrate. Pusura and prakerti are the eternal elements that cannot be separated from the world. Pusura is something spiritualistic while prakerti is more physical. Those are tended to be united and cannot be separated. The Tenggerese's belief to always keep the world balance in
Karo ritual is done by revering Sang Hyang Widi Wasa as the world's creator. In addition, in Karo ritual, Tenggerese people believe that respecting the ancestors will give blessings to the people. The ritual itself has a pure aim that people believe as the ancestors' blessing and supernatural power for welfare, tranquility, prosperity, and peace.

The local wisdom of the Tenggerese people in Karo ritual is quite interesting to investigate as an effort of documentation which is done through the description, the forms of local wisdom is also an effort to preserve the local wisdom as a cultural wealth of Indonesia.

\section{RESEARCH METHOD}

The research method used in investigating the local wisdom of Tenggerese people was descriptive qualitative which was done by describing the results deeply. This descriptive qualitative method was used for investigating in depth the Tenggerese's local wisdom in Karo ritual. Through the description, the results show a systematic, actual, and accurate portrayal of research phenomena.

This study was carried out in three different villages, they are Ngadisari, Wonotoro and Jetak in Sukapura district, Probolinggo regency, East Java. The location is on Bromo mountain. The three villages annually celebrated together the Karo ritual that its excecution was done in turns following the different location of the celebration. The observation data was obtained in Jetak, Sukapura. The togetherness of the three villages in Karo ritual has become a routine that bonds the people's cultures in a togetherness.

The data collection technique used observation which was done by observing the people's activity in the process of preparing and implementing Karo ritual. Besides, an interview was also conducted in order to get the data dealing with the implementation of Karo ritual.

\section{The KARo Ritual of Tenggerese PeOPle}

Karo is a big event that that Tenggerese people look forward because the relatives from the outside area will come and celebrate it with their family. In Karo celebration, people do a set of ritual activities starting from the activities which were done in family until the activities which were done in community. A various kinds of activity was done by the people including cleaning the house, preparing the clothes for the ritual, and also preparing sesandingan which will be used in the 
ritual ceremony. The preparation, namely cleaning the house and preparing some food, like cakes and drinks, is a preparation which should be done by each family. Those activities involves the cooperation of the family members. In the Karo ritual, the house will be visited between neighbors and family. The aim of cleaning the house is as the preparation of the visits. Therefore, the guests will be more comfortable when they visit and feel happy because of the cleanness and the served food and drinks. The preparation of Karo ritual for the family is done by preparing the clothes that will be used in the event. The color of the clothes prepared for Karo ritual can be done by the families or communities. The preparation of sesandingan for the ritual in the family is carried out by preparing not only some incenses and flowers, but also food for the offerings. Meanwhile, the sesandingan for the ritual in community scope is prepared together with the other people by preparing some offering materials and tools such as sodor, jimat kelomtong, and gamelan which are done for Sodoran ritual.

Karo ritual for Tenggerese people was done in holy places including the worship places, punden, the village crossroads, the ancestors' graves, agricultural field, fireplaces, and the places that the people use together, such as the places where they can get clean water for cooking. The people believe that those holy places have a significant role in their daily life. Therefore, a ritual is needed with sesandingan in those aforementioned places.

According to Koentjaraningrat [2], in the tradition of ritual ceremony that people do, there are four components that cannot be separated from the ritual, including the ritual place, condition or implementation, stuff, and tools both for the people who do the ritual and lead the ritual itself. In Karo ritual, the ones who lead the prayers are the shaman. They are the ones having special powers proved by their passing in shaman's examination and graduation from the Tenggerese elders. Meanwhile, the one who leads the ritual ceremony is the village's leader accompanied by the elders of the village.

Karo ritual done by Tenggerese people is started by tekane ping pitu, sodoran ritual, tumpeng gede (tumpeng ageng) ritual, sesandingan, neighbors and relatives vistit, nyadran, ujungujungan and mulihe ping pitu.

1) Tekane ping pitu is a ritual activity which is done on the seventh day of Karo month. On that day, people believe that the ancestors' spirit come to participate in Karo ritual. The coming of the ancestors' spirit is done by burning the incenses that have been given magic prayer spell by the shaman.

2) Sodoran ritual is a ritual which is done together by the people in the village hall. It is started by doing march around the village accompanied by gamelan sound and ended in the village's hall. In that march, there will be a point where the villagers from three different villages will meet in a certain place and they go together to the village's hall in order to do sodoran ritual. The sodoran ritual is led by a shaman. During this ritual, the men gather in the hall and do sodoran dance in turn. Sodoran is a holy dance of Tenggerese people that is done in Karo. The dance is performed by four dancers facing each other with certain distance and walk until they meet each other in the middle and go back distant again. The dancers do dance moves with their index finger points to the top. This dance is done in turns by the people until every villager get their turn to perform the dance. The Javanese musical instruments used in this sodoran dance are gendhing janten, rancakan, titir and surabalen, while the musical instruments for accompanying are gendhing which consists of kendang, peking, saron, bonang, kenong, gambang, slentem, and gong [3].

3) Tumpeng Gede or Tumpeng Ageng ritual is a complementary ritual carried by the villagers as the welfare offerings. The activity is done in the village's hall and all the families bring tumpeng. The ritual ceremony is led by a shaman and after the shaman has finished reciting the prayers, the people go home with the tumpeng to be used in their own ceremonial meal at home.

4) Sesandingan ritual is an activity in which people prepare some offerings for ceremonial meal at home and at some places that people regard as holy places. For the people, sesandingan is used as a way to get them closer to the ancestors' spirit in order to protect their family. When sesandingan is already prepared in the people's houses, the shaman goes around from one house to another house in order to give welfare prayers through the magic spells. The offerings put in a small container that has been given prayer by the shaman is carried to the holy places. According to Koentjaraningrat [2], the offerings that put in the holy places will arrive to its destiny, the ancestors.

5) Relatives and neighbor visit is an activity that Tenggerese people do during Karo. The ritual is done to strengthen the confraternity bond. During the activity, the guests have to eat and drink the food and drinks that have been prepared by the hosts. By doing that, it is believed that it will give happiness to the hosts and bring on blessings to them.

6) Nyadran ritual or what is called sedekah panggonan is an activity which is done by the people together by visiting the graveyards. It aims at giving homage to the ancestors' spirit. In nyadran ritual, the villagers bring on some food and drinks as the offerings for the ancestors' spirit. After all the villagers gather in the graveyards of their families, the ritual ceremony is led by the shaman by reciting the prayers and the prayers are continued by the villagers.

7) Unjung-unjungan ritual or unjung-unjung dance is an activity done after nyadran taking place in front of the village hall. The ritual is in the form of dance involving two men moving following the gending rhythm and, for sometimes, hitting the other dancers' back with a rattan. Unjung-unjung dance portrays the adroitness and invulnerability of a man with a message that who hits will be hit too [3]. The dance is an expression of gratitude for the blessings that have been got. Simultaneously, the people express their gratitude by dancing. The beltings are the symbols of hardships in life that humans need to always grateful and have self-reflection. Accomplishing the hardships together will make it lighter and feel easier for Tenggerese people.

8) Mulihe ping pitu is the last ritual in Karo in which people believe that the ancestors' spirit goes back to their place. This ritual is done by each family following the process of bringing on the incenses to the shaman's house to be given magic spell which is later on used to return the ancestors's spirit by burning them. 
In Karo ritual, it is found the existence of some children during the ritual. It shows the regeneration of the effort on preserving the culture that Tenggerese people do. Bahrudin [4] explains that the involvement of family in Tenggerese's tradition is a way to preserve the local culture of Tenggerese people and, moreover, it is compulsory for the teenagers to follow the tradition done by the people.

\section{A. The Local Wisdom of Tenggerese People}

Tenggerese people really respect the tradition that is a heritage from the ancestors. Sutarto [3] explains such tradition as an appreciation that is derived from the ancestors and becomes the local wisdom of the Tenggerese people. They really keep the tradition. They are afraid of breaking the tradition because they avoid to get the social sanction by the others. The tradition is hold strongly by the people since that kind of religious tradition will give meaningful experience that becomes the people's power and identity. The religious activity will give a factual experience which relates to the feeling and behaviors that can make individuals or community get the meaningful experience [5] [6].

The form of local wisdom that Tenggerese people keep until nowaday is the obedience and loyalty towards four types of teachers (guru papat), including Sing Kuwasa (God), guru wong tuwa (parents), guru pemerintah (government), and guru ngaji or pasinaon. [3].

1) Obedience and Loyalty towards Guru Sing Kuwasa (God) The Tenggerese people are obedient towards the world's creator who creates skies and earth, that is the God or the one whom they call as Hyang Whidi or Hyang Whidi Wasa. The obedience can be seen when they do the traditional ritual by giving the first offering to Hyang Widi. It can be seen also through the prayers said which mention that Hyang Widi will protect them, the people, as well as their environment.

\section{2) Obedience and Loyalty towards Guru Wong Tuwa (parents)}

The obedience toward the parents who have guided and raised the children is done through the behaviors and the blessings in certain activities. The parents' blessings are believed bringing the success in their children's lives and when the children do not get the parents' blessings, it will harm to their lives.

3) Obedience and Loyalty towards Guru Pemerintah (government)

The government for Tenggerese people are the ruler and his staffs which currently become the leaders in the village. The ruler protects the people using the laws which are valid for the citizens. The ones who live in the surroundings are the village leader and his staffs. The leader of the village in Tengger is called Peting i.

4) Obedience and Loyalty towards Guru Ngaji or Pasinaon Guru Ngaji or Pasinaon is the one who is deemed to have knowledge to share with the people. Guru Ngaji is a shaman which people see as the one who has religious knowledge and tradition that people can learn from. Meanwhile, pasinaon is a teacher who gives knowledge to the people in the school. Both teachers are respected by the Tenggerese people.

\section{B. The Function of Obedience on the Karo Ritual}

Karo is a big day for Tenggerese which is celebrated annually. The Tenggerese people are eager to wait for Karo because there will be a family gathering on that day. Those who are apart will be joined on the day. Togetherness cannot be separated from the ritual function. It is the institutional relationship with the society. The ritual function is not only for the fulfillment for the people's need, but also the learning for the society to change their behaviors [7]. The people's participation in Karo ritual will bring such encouragement in fulfilling someone's need and also it will be such learning traditional culture that some day later will be inherited by the next generation.

The event of Karo ritual is held meaningfully by the Tenggerese people for their survivals. Spradley [8] argues that the culture is created by using any events symbol that shows to the things which involves what is felt and experienced. The example can be seen in Karo ritual which is annually done by the people. Geertz [6] states that the constancy in the culture becomes the implied human's experience within the formation of symbols.

The mutual cooperation of both tradition and helping each other in the ritual is strongly attached to the people. Therefore, the Tenggerese people can maintain their cultural tradition. The harmony concept which is shared by the Tenggerese is a local wisdom which is still believed by the society. It is said that "sugih donya, nek sugih dulur, anguk sugih dulur" which means it is better to have friends than much money [3].

Karo ritual is harmoniously held by the Tenggerese that it even becomes the existing local cultural wisdom until nowaday. The implementation of Karo ritual is done by the people in case of their obedience to the embraced cultural tradition. The implied cultural significant in Karo ritual can be seen through the cultural symbols existing during the ritual, the implementation of the ritual, within the things or tools for the ritual and the people who perform and the leader of the ritual. Spradley and Mc. Curdy [9] stated that to know the cultural significance, it is important to see it through symbols, because the meaning can only be seen through symbols.

The cultural meaning embedded in Karo ritual is seen as the function of obedience to perform the ritual to be safety, quiet and peaceful. Those meanings are categorized in the form of connotative or personal meanings, as exposed by Spradley [9] \& Mulyana [10] that meaning is referential and subjective.

The Tenggerese people has a belief that Karo ritual should be annually done. The symbols are presented through society's participation whether individually or as a whole society to join all the activities in the ritual. By joining all the activities in Karo ritual, it is assumed that the whole families and the community of Tengger will stay safe. The people believe that Shang Hyang Widi will protect the society, the Tenggerese people, and the environment. The belief of that safety becomes the reason of the people to keep maintaining Karo ritual.

The peaceful meaning will be felt when the people follow all the activities of Karo ritual. Every Karo ritual starts from tekane ping pitu, Sodoran ritual, tumpeng gede ritual (tumpeng ageng, sesandingan (facing each other), family and neighbor 
visit, nyadran, ujung-ujungan and mulihe ping pitu. Those all meanings are revealed through cultural symbols.

Living in the society needs a good communication between neighbors, citizens, village officials, and village elders and also between individuals within the society. By doing a good communication in Karo ritual, peace will be easily achieved. The social life will be tranquil, peaceful, and safe in the kinship.

\section{CONCLUSION}

The Tenggerese people celebrate Karo every second month of the Saka Calendar which concurs on the seventh day and it is done in 15 days respectively. Karo day is worship towards the creator and the respect towards ancestors' spirit. Karo ritual is carried out in a set of activities followed by the entire Tenggerese people. The set of activities starts from Tekane Ping Pitu ritual, Sodoran ritual, Tumpang Gede ritual (tumpeng ageng) sesandingan, family and neighbor visit, nyadran, ujungujungan and mulihe ping pitu. The local wisdom of Karo ritual is reflected in the tradition of obedience which is implemented through a set of activities of Karo ritual. People believe the obedience of Tenggerese people towards a ritual means safety, tranquility, and peace in Tenggerese people's lives.

\section{REFERENCES}

[1] H. Sutrisno, Metodologi Penelitian, Yogyakarta: Andi Yogyakarta, 2000.

[2] Koentjaraningrat, Kebudayaan Mentalitas dan Pembangunan. Jakarta: PT. Gramedia Pustaka Umum, 1992.

[3] A. Sutarto and S.Y. Sudikan, Pemetaan Kebudayaan Propinsi Jawa Timur; Sebuah Upaya Pencarian Nilai-Nilai Positif. Jember: Biro Mental Propinsi dan Kompyawisda Jatim, 2008.

[4] B. Bahrudin, Masrukhi, and H. T. Atmaja, "Pergeseran budaya lokal remaja suku Tengger di Desa Argosari Kecamatan Senduro Kabupaten Lumajang," J. Educ. Soc. Stud., vol. 6, no. 1, pp. 20-28, 2017.

[5] R.W. Hefner Hindu Javanese: Tengger tradition and Islam. Princeton, N.J: University Press. 1985.

[6] C. Geertz, "Thick Description," in The Interpretation of Cultures, 1973.

[7] B. Malinowski, The Dynamics of Culture Change: An Inquiry into Race Relations in Africa. New Haven: Yale University Press, P.M. Kaberry, ed. 1946.

[8] D. W. McCurdy, J.P. Spradley, and D. J. Shandy, The cultural experience: Ethnography in complex society. Waveland Press, 2004.

[9] J. P. Spradley, and D. W. McCurdy, Anthropology: The cultural perspective. New York: Wiley, 1975.

[10] D. Mulyana, Ilmu Komunikasi Suatu Pengantar. Bandung: Remaja Rosdakarya, 2000. 